\title{
Planning, design and use of the public space Wahlenpark (Zurich, Switzer- land): functional, visual and semiotic openness
}

\section{Heidi Kaspar, Elisabeth Bühler, Zürich}

\section{Introduction}

This article focuses on Wahlenpark, an urban public green space in Zurich. Like other public spaces such as plazas, squares or boulevards, parks are celebrated by urbanists as inclusive places, as places for «all» where strangers meet (SANDERCOCK 2005; WARD THOMPSON 2002). However, there is a vast literature on exclusionary processes in public space showing that public spaces are contested spaces, imbued with unequal power relations, where different normative visions on publicity struggle for assertion (e.g. Belina 2006; Mitchell 2003; SMITH 1996). Some authors argue that neo-conservative forces have recently replaced liberal democratic conceptions of public space legitimizing displacements of marginalized people from public space (BeLINA 2006; MrtCHELL 2003). SмIтH (1996) states that since the 1980s parks have been built in a more clearly arranged manner for the purpose of social control. Feminist authors, however, question whether public spaces have ever been democratic spaces. They argue that democratic inclusion in public space and the Lefebvrian notion of the «right to the city» (MrTchell 2003) mainly reflects white, male, bourgeois experiences and that women together with some groups of discriminated men have been denied equal access until the present day (e.g. BondI \& DOMOSH 1998; Fenster 2005; García-RAMON et al. 2004; Pain 2001; Paravicini 2003; Ruhne 2003; see also Vaiou \& KALANDIDES in this special issue).

The aim of this article is to show the manifold perceptions and experiences on inclusion and exclusion of one and the same public place. For this purpose, the diverse spaces that have been created in Wahlenpark are presented and analysed from a constructivist point of view. The following section of the paper discusses the theoretical background of analysis, the methods applied and the research context. Section three presents and discusses the meanings of Wahlenpark for the three main types of actors identified. Issues of exclusion and inclusion at Wahlenpark are deliberated in the concluding section of the article.

\section{Theory, methods and research context}

In compliance with Löw (2001: 13), spaces and places are conceptualised here as being constituted through action. From this perspective, space is a relational order(ing) (German: (An-)Ordnung) of bodies (understood as social goods and people) (ibid: 131, 153f.). Hence, actions and humans are both components of space (ibid: 154f.). Relational spaces, as the product of social construction processes, are thus fundamentally dynamic, processual and changeable - always in the process of being made (Löw 2001; MASSEY 2005; more on this concept in the editorial of this special issue).

The findings presented in this article are based on semistructured interviews with park users met in situ in the spring and summer of 2006 and 2007, semi-structured interviews with planners and designers and documents of the municipality of Zurich. All three types of data have been analysed with the coding procedures of the Grounded Theory Methodology according to StRauss \& CORBIN (1998).

This research is part of a larger project titled «Sustainable Design, Management and Appropriation of Urban Public Parks», supported by the National Research Program (NRP) 54 of the Swiss National Science Foundation (SNF). Capitalising on a mixed methods approach, the project aims to identify elements of design, planning and management, which facilitate a socially sustainable appropriation of public areas (see also OstermanN \& TrMPF in this special issue). The research focuses on three case studies in the city of Zurich, Wahlenpark being one of them. Inaugurated in summer 2005, Wahlenpark is the last of four recently created parks in the neighbourhood of Neu-Oerlikon. Neu-Oerlikon is one of the largest inner city conversion areas in Switzerland. During the last 20 years, an elaborated public private partnership planning process between the landowners and the municipality of Zurich was carried out. The creation of public spaces of high standing quality - including the creation of four new parks - was one of the planning priorities aiming at enhancing the neighbourhood's image.

Wahlenpark is chosen as a focus here as it represents a park design typical not only for recent parks in Zurich but for other cities in Switzerland as well: a park in the sober architectural style of modern severity (Weilacher 2001: 13). According to Holland \& StRASSEL's (1996: 12f.) reflections on the design of parks, Wahlenpark also contains considerable elements of a postmodern park. Thus, Wahlenpark does not offer any signification and norms precoded with an unambiguous intention. For a qualitative research perspective relying on people's narratives, this low 
degree of institutionalization of the site is an advantage. According to Löw (2001: 161f.), the production of space is not normally a discursive act but a routinized one difficult to access. Hence, both the newness to people and the challenge of interpretation, enhances the need for discursive reflexion by its users, thereby facilitating narratives.

\section{Meanings and experiences of Wahlenpark for different types of actors}

Three types of actors are identified as being connected to the development of Wahlenpark: city planners, designers and visitors. City planners, in the role of the constructor, specified their requirements and prospects for the future park and published a design competition. The designers, who drafted a design concept, interpreted the planning requirements. This mental space of the designers was then implemented. Visitors to the park now sojourn in it, pass through or ignore it - thereby creating their own spaces. In the following sections the productions of spaces by the actors defined above will be analysed in more detail. It will be shown that openness is a key element of all produced spaces and that this openness can take on different forms: functional, semiotic and visual.

\subsection{The Wahlenpark of the planners: a hybrid space between school sports facility and public park for the neighbourhood}

In the case of Wahlenpark, the municipality of Zurich was the responsible constructor. The analysis of documents (Grün Stadt Zürich, September 2001; Stadt ZÜRICH, GARTENBAU- UND LANDWIRTSCHAFTSAMT, May 2001) shows that Wahlenpark was scheduled by city planners from the very beginning as a hybrid free space serving as an open sport ground to the adjacent school of 800 pupils and as a multifunctional place for the neighbourhood. Although the planning process of Wahlenpark was confined to a group of appointed experts, it mirrors a notable commitment on the part of the municipality planners to create a space where «everybody» can feel comfortable and safe. In 2001, the municipality launched a design competition. The announcement contained several criteria expressing the intended social functions of the park:

- suitability for miscellaneous stakeholders and a heterogeneous public,

- a large flat lawn for games,

- avoidance of elements directed at the needs of specific groups or events,

- acknowledgement of the safety requirements for park use at dusk and at night.

The identification of the target audience as miscellaneous stakeholders and a heterogeneous public may seem unspecific at first sight. Yet, supported by the demand to abstain from monofunctional park elements, this vagueness can be seen as an intentional choice of functional openness (German: Nutzungsoffenheit), reflecting a vision of Wahlenpark as «a place for all», as a multifunctional, and thus, inclusive public space. Hence, a request to pay attention to social diversity may be identified.

Yet, in the same announcement, planners confine the degree of inclusiveness by specifying the aspired main user groups as residents, pupils and employees. This ambiguous definition of the target audience is a direct result of the double tracked characterisation of the place as a school sports facility and a public park for the neighbourhood. Whereas a school sports facility is an earmarked open space with defined priorities of use, a public park is a multifunctional space open to various user groups at the same time (GRÜN STADT ZÜRICH 2006). As a result of this hybridism, the planners created a functionally open space, i.e. a space for sports and physical activity without defining what kind of activity.

The planners further curtailed the primarily targeted inclusiveness of the space by making no mention of people largely or partly excluded from urban public spaces in general, such as females, marginalised persons and senior citizens (LANDOLT et al. 2006; see also the cited literature in the introduction paragraph). The planners' vision of Wahlenpark as a «place for all» must therefore be called a half-hearted one, as an effort to actively include all kinds of people is missing.

In the following section, the designers' interpretation and implementation of the requirements of the planners is discussed in more detail.

\subsection{The Wahlenpark of the designers: «the pure, large area»}

The first prize of the design competition was awarded to the project «RGB» of the bureau of landscape architecture Dipol Landschaftsarchitekten (since 2008 Fontana Landschaftsarchitekten), Basel, and the artist C.T. Hunziker in Zurich. «RGB» stands for «red, green and blue», the colours which constitute Wahlenpark. According to the design concept, each colour constitutes a separate area: red stands for a corpus of red beech trees, green for the grass playing field and blue for a concrete element («long bench») with blue glass bricks, illuminated from inside at night (see Fig. 1 and Fig. 2). The architects prioritized the aspect of action by ascribing a maximum of space to this function. However, the designers explicitly put no installations - such as paths or football goals - on the lawn to avoid any pre-structuration of use. Hence, a semiotic open space has been created. In this context, «semiotic» refers 

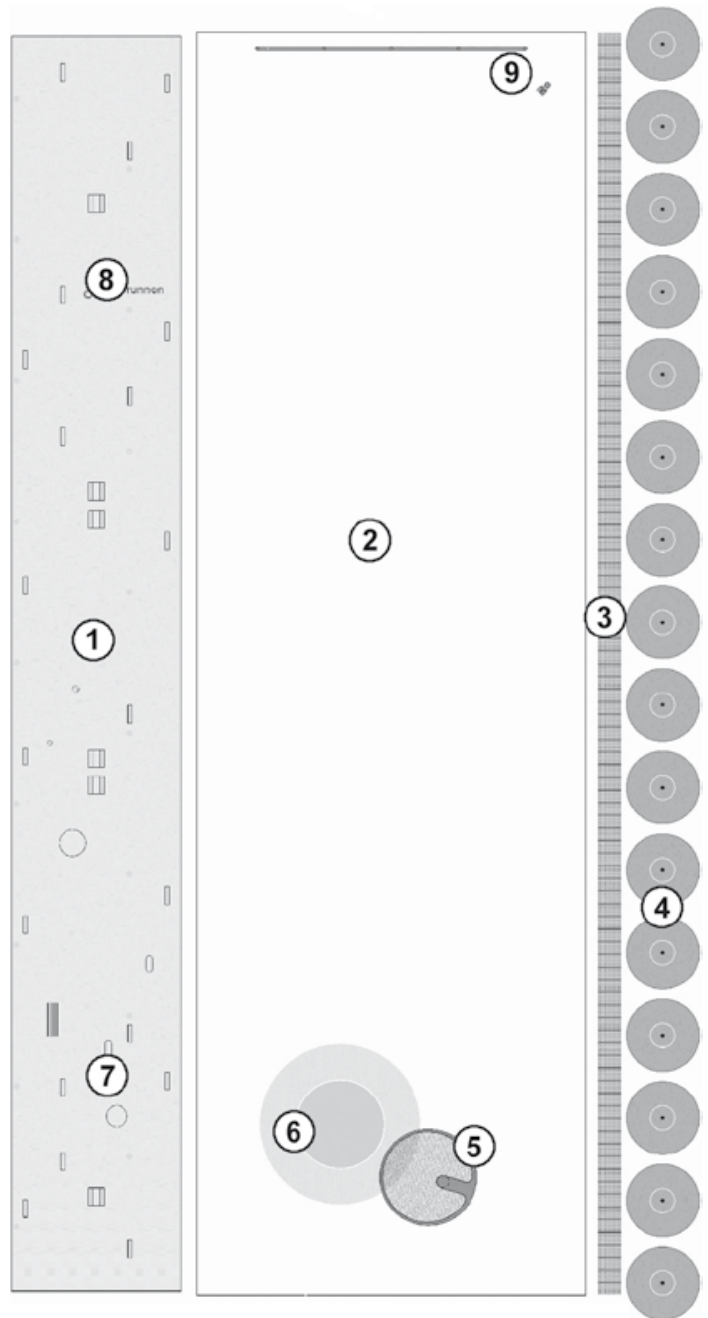

1 Gravel with beeches (not shown), benches and tables

2 grass

3 long bench

4 lime trees

5 roof providing shade

6 water basin

7 playground equipment

8 water fountain

9 ball catch fence and flood light post

1 gravier avec des hêtres (pas montrés), des bancs, et des tables

2 pelouse

3 banclong

4 tilleuls

5 toit donnant de l'ombre

6 bassin

7 équipment de jeux

8 fontaine

9 clôture arrête-ballon et mât de lumière

1 Kiesbelag mit Blutbuchen (nicht eingezeichnet), Sitzbänken und Tischen

2 Wiese

3 Sitz- und Liegeelement

4 Linden

5 Schattendach

6 Wasserbecken

7 Spielgeräte

8 Trinkbrunnen

9 Ballfanggitter und Flutlichtmast

Fig. 1: Plan of Wahlenpark (Zurich, Switzerland)

Plan des Wahlenparks (Zürich, Schweiz)

Plan du Wahlenpark (Zurich, Suisse)

Source: GrÜN STADT ZÜRICH (original plan); cartography: F. Ostermann, M. STEINMANN

to the different significances an object may adopt for different people. Consequently, the responsible landscape architect called the playing field «the pure, large area» and added: «Here, people have to negotiate how to use this space themselves».

According to Mrtchell (1995: 120), a space is not «truly public», when there are assigned places for specific use, such as a volleyball field for example. Because clear ascriptions of places pre-structure the pattern of users and exclude certain groups, whose legitimisation as members of the public is as a consequence put in doubt. Thus, leaving the potential use undefined, the designers of Wahlenpark adapted the planners' vision of a «place for all» and in doing so created ideal preconditions to foster diversity and to facilitate the encounter of different social groups.

However, the «playing field» is not as «pure» of prestructuration as intended by the designers. Viewed 


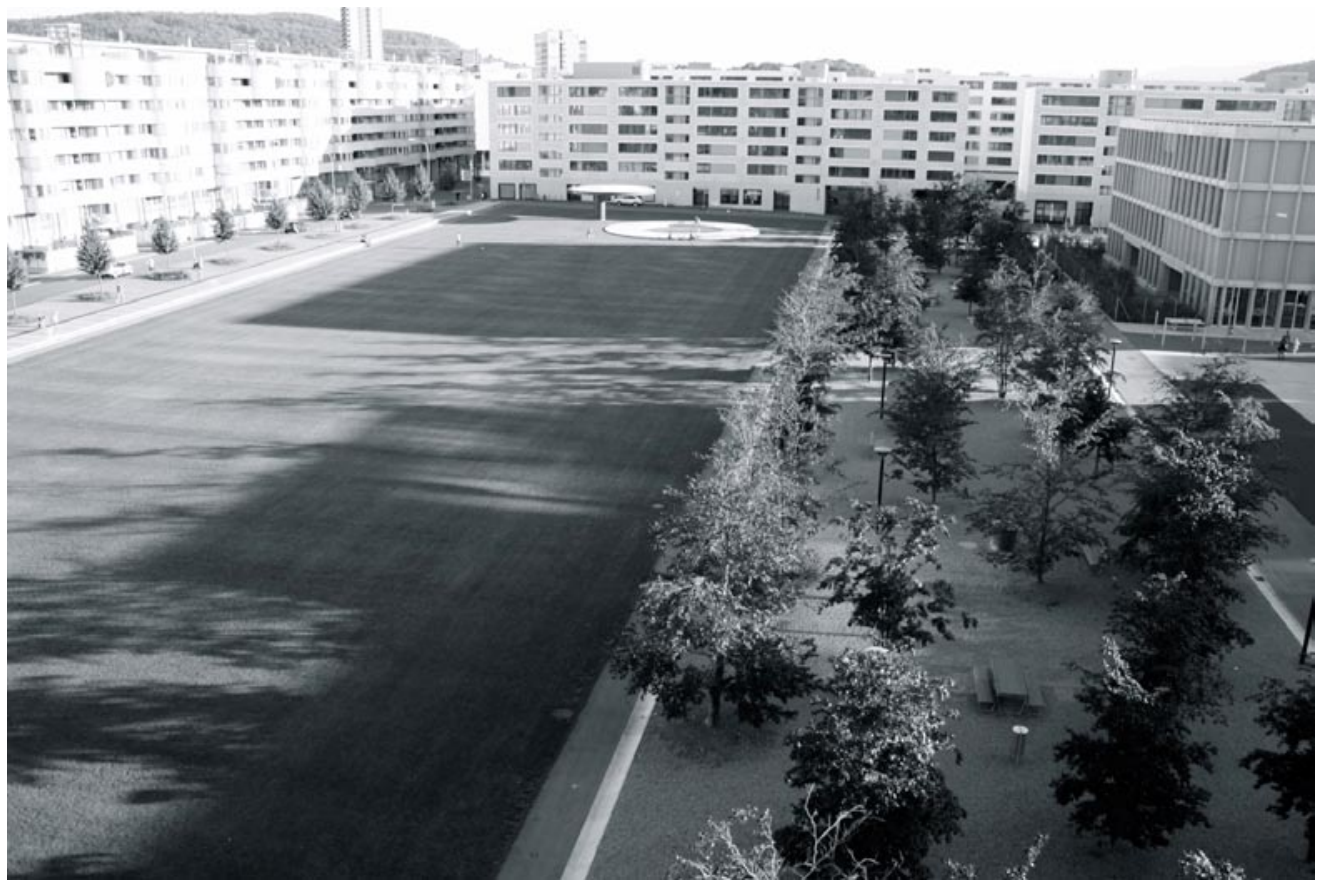

Fig. 2: Bird's eye view of Wahlenpark in Zurich (Switzerland) with the bosk on the right, the lawn in the centre, the concrete element on the left and the water basin in the background Der Wahlenpark in Zürich (Schweiz) aus der Vogelperspektive. Auf der rechten Seite ist der Buchenhain zu sehen, in der Mitte die Spielwiese, links der Sitzbalken und im Hintergrund das Wasserbecken.

Vue aérienne du Wahlenpark de Zurich (Suisse). A droite se trouve le bosquet, au milieu la pelouse, à gauche l'élément en béton et en arrière-plan le bassin.

Photo: H. Kaspar, September 2007

from a signal perspective (whereas signs are understood as legible material elements; see HАмм 1982: 36 ), it would seem that the space of the playing field is pre-structured, albeit in a subtle way. The fence, put there in order to keep balls from rolling away, and the illumination mast evoke the atmosphere of a football stadium (see Fig. 3). These sculptural steel construction elements remind the viewer more of ball games, in particular football, than of other activities, such as sun bathing or picnicking. Indeed, both the designers and MrTCHELl (see paragraph above) are mistaken by assuming that a lawn is per se a «pure, large area» with no inherent codes of practice. In fact, the difference between the level of pre-structuration of a volleyball field and a flat lawn is only a gradual one.

A research project on public free spaces in different European cities directed by PARAVICINI shows that parks containing open areas functionally earmarked for physical activity are usually appropriated by men and boys (PARAVICINI 2003; see also GARCÍA-RAMON et al. 2004). Women and girls sojourn at the peripheral areas of parks, where there is seating-accommodation and from where events can be followed. At Wahlenpark, the bosk with its benches (see Fig. 1) can be identified as such a peripheral space of retreat. But Wahlenpark also contains semiotic open elements and blurred boundaries that support non-stereotypical gender patterns of use (STUDER 2002): In the case of the concrete element for instance, the boundaries between the areas of action and retreat are blurred due to its semiotic openness. On the one hand, according to the responsible designers, this park element is conceptualised as a «tribune to the playing field». On the other hand, the concrete element is visible from most parts of the park and its design invites users to play on it. For this reason, the concrete element acts as a stage as well. Feminist planning practice gives evidence that such permeable boundaries have the potential to diminish gender segregation within public parks (STUDER 2002). 


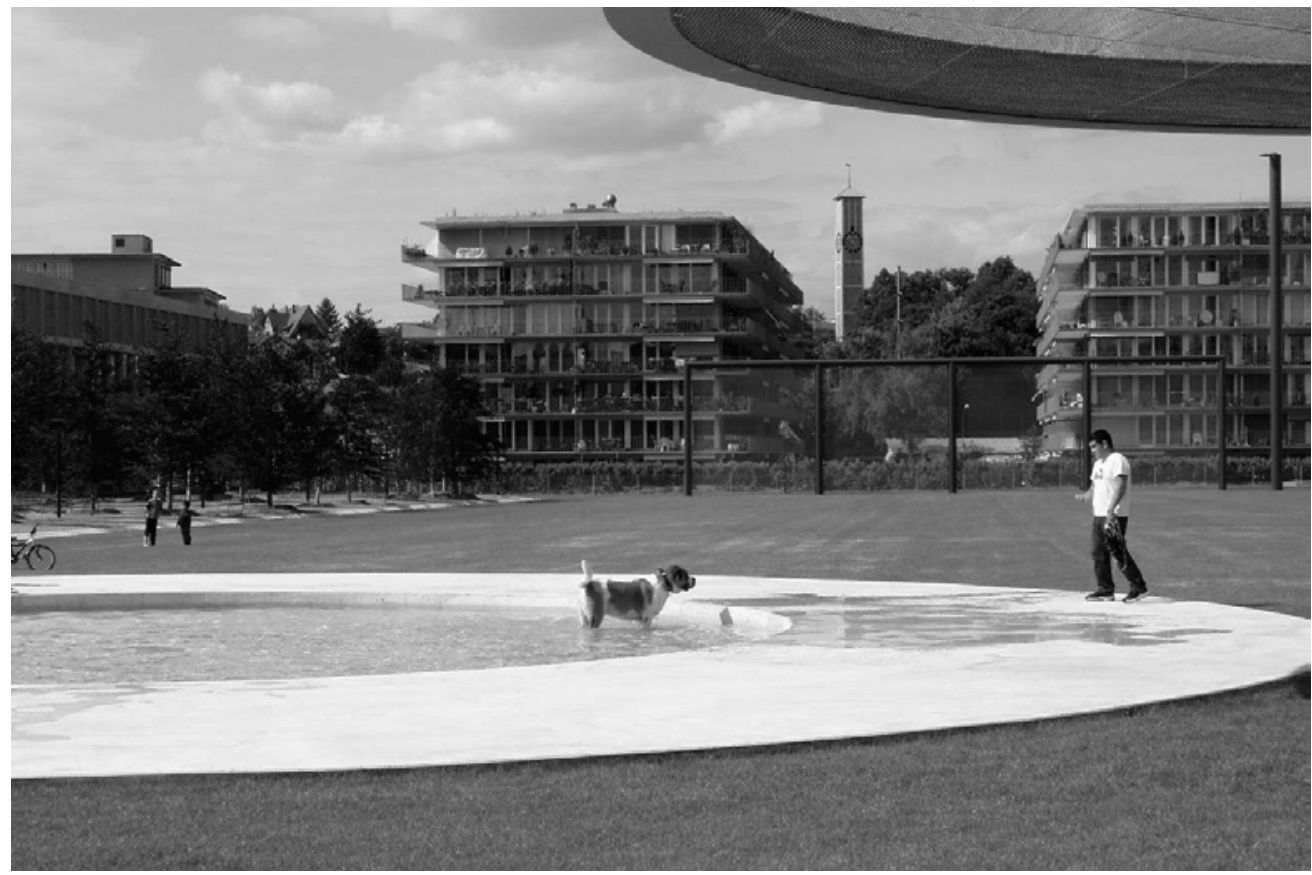

Fig. 3: Water basin at Wahlenpark with ball catch fence and flood light post in the background Das Wasserbecken im Wahlenpark, im Hintergrund das Ballfanggitter und der Flutlichtmast Le bassin du Wahlenpark avec en arrière-plan la barrière et le projecteur

Photo: by courtesy of F. Sснмiт, summer 2005

In the following section, attention is given to the ways people sojourning at Wahlenpark deal with these opportunities - what kinds of spaces do park users produce?

\subsection{The Wahlenpark of the people \\ Creative and nostalgic spaces: a sense of belonging.} The semiotic open space that designers produced at Wahlenpark invites interpretation and offers an opportunity to independently and creatively interpret the space according to personal needs. A 26 year old female student uses the word «fountain» for the element that is called water basin by planners and designers and is predominantly used by children to flounder about in the water. The woman lives in the neighbourhood and loves to relax near the water. If she lacks time to visit her favourite place at the lake of Zurich, she goes to the nearby «fountain» in Wahlenpark instead. For her, this «fountain» is not an ordinary one. Contrary to other fountains in the city, this one permits the direct contact with water and therefore invites her to relax nearby. In this way, the «fountain» functions as her substitute lake.
A 57 year old nearby resident explains that his favourite part of Wahlenpark is the group of copper beech trees. «It also has to do with childhood memories. (...) my parents had a huge copper beech behind their house (...). For me, it is simply the most magnificent tree» (male resident, 57).

In a very intuitive and straightforward way he feels familiar with the place because this specific tree has a particular meaning for him. This situation is a random reality that is almost impossible to plan. However random, memories serve as links between a place and the personal history and therefore are links from where a sense of belonging can be developed.

Thus, both the reinterpretation of space according to one's personal needs and the discovery of a childhood memory in a park element are examples of ways of becoming familiar with a place. According to FENSTER (2004a), feeling familiar with a place is an important element of a sense of belonging.

«Not really a park»: no sense of belonging. A 32 year old nearby resident is disappointed with the design 
of the place because neither her functional nor her aesthetic needs are met. Her aesthetic needs would require a greener park scenery. She finds the bosk not green enough as the leaves of the trees are always «brown like in fall». Wahlenpark is for her, therefore, «not really a park». The woman also addresses functional deficits. When she is outdoors, she is usually accompanied by her two young children and looks for a place for them to play. At Wahlenpark, instead of a playground she has to orientate herself around isolated playground equipment, equipment that she perceives as too dangerous for her children and too exposed to the sun. She would feel far more comfortable if she did not have to worry about the safety and health of her children as much as is now the case. Her perception of Wahlenpark is one of emptiness and dislike. Although she lives next to the park, it remains a strange place to her; she has no sense of belonging. The resident's struggle to give meaning to the place - to read the place - illustrates that semiotic openness is not only a chance for creative interpretation, but also a request to do so. And as legibility of a place is a central condition of appropriation, semiotic openness can also function as a barrier to appropriation of space. In this case, a person belonging to the defined target audience (see section 3.1) becomes an excluded person.

Feeling safe or feeling exposed: a sense of comfort? In contrast to the above quoted mother, a teenager - a nearby resident, too - feels comfortable in Wahlenpark. She highlights the opportunity the park gives her to be outdoors on warm summer nights because she perceives it as a safe place:

«Yes, and above all you don't need to be afraid that, well, that nobody comes here, because it is so open. Thus, people just see the place and that's why you feel comfortable. You are safe, well as a woman, and then this [to be here at night] is no problem» (female resident, 16).

The teenager perceives the place as «open» concerning visibility in two different meanings. First, the park can be viewed from the outside, because there are no clear boundaries to the surrounding areas. The sensation that people can or actually do look from the outside into the park is supported by the fact that residential buildings enclose the park on three edges. Second, the person refers to open visibility deriving from a well arranged interior: the park has a flat topology that is weakly structured, leaving no unclear niches, where «weird persons», as she said, could be lurking around. The well arranged interior of the park allows the teenager to sojourn in public space far into the night on her own, to control space and therefore supports her autonomy.

Yet, simultaneously, her autonomy is impaired by her confidence in and dependence on the social control by others. The same visual openness appreciated by the teenager is experienced in a clearly negative way by a 54 year old female visitor. This visitor stated that she would never relax on the lawn because «on it you feel exposed». Through this exposure to the gaze of others, she feels controlled and misses security. Thus, the described examples illustrate two totally different experiences of the visually open park architecture. Visual openness provides a space of social control. For one user, this evokes a feeling of safety and hence comfort. For another user, this leads to a feeling of being exposed and thus discomfort.

Furthermore, the fact that the teenager reflects on her feeling of safety «as a woman» mirrors the paradox of gendered feelings of safety in public space, described by RuHNe (2003): from a statistical point of view, it is men who are at risk in the public space and it is in the private sphere, where women should fear harassment most. According to KuTschinske \& MeIER (2000), such a paradox situation is sustained by the dominant public discourse of women's fear in public space. The consequences of this discourse are effective: WeSELY \& GAARDER (2004) describe how women constantly negotiate their concern and needs referring to their activities in public space. The frequently chosen strategies to avoid certain places and/or times signify a deficit of autonomy, a confinement of free space of movement and an arrangement with discriminating social structures. As a consequence, women's fear of violence results in the partial exclusion of women from public space (FENSTER 2004b).

\section{«Here, people have to negotiate how to use this space} themselves»: a place of encounter. When several persons simultaneously seize the chance for reinterpretation of space it might result in a situation like the following one:

«I was just resting here after eating my lunch, just resting here by myself, when this adult man, I don't know what he was doing, somehow hit against this wall with a ball again and again and it disturbed me and so I asked if he could not go somewhere else as I would only be staying here for five more minutes and if he could not take a break for five minutes because I wanted to rest a little and then he said that he too would only be here another five minutes, but anyway he then went, he said it was okay» (female visitor, 54).

The situation described above illustrates how different requirements and needs lead to different interpretations of one and the same park element. Whereas the woman spending her lunch-break outdoors wanted to rest, stretching out on the concrete element (the «wall»), the man thought it an ideal place to practise football. This example shows that semiotic openness does not prevent conflict, it might even provoke it and, as a consequence, results in a situation where people have to bargain their entitlement to space - just as the 
designers intended it (see paragraph 3.2). Mitchell (2003) regards such "places of unmediated interaction» as an essential political need for marginalised people as it creates opportunities for them to (re-) claim their «right to the city». Thus, semiotic open park elements can be understood as offering a space of selfdetermination - not only on a political but also on an ordinary level, too.

\section{Conclusions}

It has been emphasised above that openness is an important reference point in the production of spaces at Wahlenpark by planners, designers and users, albeit with different meanings. The openness of the city planners is a functional one. They aim at a multifunctional, inclusive place by not defining specific uses. Designers emphasise the functional openness of the city planners by reducing infrastructure to a minimum and by installing park elements without clear codes of practice, encouraging experimentation and creativity in play. In this way, designers created a semiotic open, minimally pre-structured space. The statements of park users show that they experience openness differently, sometimes even in a contradictory manner.

Semiotic openness is seen as a chance to creatively interpret a place and find anchor points by which to become familiar with it, as well as an ideal condition for «unmediated interaction» fostering social inclusiveness and self-determination in public space (Mitchell 1995). But, semiotic openness can also have exclusionary effects. When a perceived space does not correspond to users' needs or personal imaginations of a public space and/or does not offer any anchor points, the semiotic openness might become illegible. According to НАмм (1982), in such a case, the sender and the recipient do not share a common pool of symbols and for this reason, communication fails. Semiotic openness also bears the risk of displacement. Situations where a person has to defend her or his entitlement to space can be seen as temporal interruptions of a person's appropriation (see Goffman 1982). Thus, semiotic openness bears the potential to both include and exclude people.

Also visual openness is experienced conflictingly. It can result both in a feeling of safety and comfort and in the sense of discomfort and exposure. These contradictory emotions of one and the same place highlight the variability of subjective perceptions. They also draw attention to the ambivalence of safety conceptualised as a question of physical measures: the momentary feeling of safety is bought dearly by social control. The possible gaze from the surrounding apartments and the permeable arrangement of the park elements create a situation of constant potential control at Wahlenpark, which according to BeLina (2006), KLAUSER (2007) or SмIтH (1996) disciplines people or even keeps them away.

Visual openness as a means of safety also reinforces the dominant discourse on women's fear in public space, which stereotypically views women as victims of crime and leaves the safety paradox untouched. Concepts of safety, which include confidence, autonomy and respectful self-regulation (PARAVICINI 2003) would seem to be far more effective, because they affect the social structures from which women's fears in public space stem.

In conclusion, it is argued that functional, visual and semiotic open spaces bear the potential to become inclusive. By offering an area of self-regulation, city planners and designers provide a democratic space. This is essential to facilitate equal opportunities in respect of the use of public spaces. It is not sufficient, though. Whether a place is experienced as an inclusive space (where one feels a sense of belonging) or an exclusive one depends highly on the social, situational and personal context. While being a form of social structure, spatial structures are not free of hierarchies, such as gender differences. As these structures affect the production of public space, they have to be incorporated in the planning and designing thereof in a more thorough and resolute manner.

\section{Acknowledgment}

The authors thank the Swiss National Science Foundation (SNF) for financial support.

\section{References}

Belina, B. (2006): Raum, Überwachung, Kontrolle: Vom staatlichen Zugriff auf städtische Bevölkerung. - Münster: Westfälisches Dampfboot.

Bondi, L. \& M. Domosh (1998): On the contours of public space: a tale of three women. - In: Antipode 30, 3: 270-289.

Fenster, T. (2005): The right to the gendered city: different formations of belonging in everyday life. - In: Journal of Gender Studies 14, 3:217-231.

Fenster, T. (2004a): The global city and the holy city: narratives on knowledge, planning and diversity. Harlow, New York: Prentice Hall/Pearson Education. Fenster, T. (2004b): Gendered cities. Notions of comfort, belonging and commitment in London and Jerusalem. - In: Cortesi, G., Cristaldi, F. \& J. DroogLEEVER FortuiJn (eds): Gendered cities: identities, activities, networks. A life-course approach. - Rome: Società Geografica Italiana: 25-41.

García-Ramon, M.D., Ortiz, A. \& M. Prats (2004): 
Urban planning, gender and the use of public space in a peripherial neighbourhood of Barcelona. - In: Cities 21, 3: 215-223.

Goffman, E. (1982): Das Individuum im öffentlichen Austausch: Mikrostudien zur öffentlichen Ordnung. - Frankfurt am Main: Suhrkamp.

GRÜN STADT ZÜRICH (2006): Das Grünbuch der Stadt Zürich: Integral planen - wirkungsorientiert handeln. - Zürich: Grün Stadt Zürich.

Grün Stadt Zürich (September 2001): Friedrich Traugott Wahlen-Park Zentrum Zürich Nord: Projektwettbewerb. Bericht des Preisgerichtes. - Zürich (unpublished document).

Намм, B. (1982): Einführung in die Siedlungssoziologie. - München: Beck.

Holland, Y.J. \& J. Strassel (1996): Zur semantischen Analyse neuerer öffentlicher Plätze in europäischen Städten $-=$ - Agis-Texte 12, Oldenburg.

KLauser, F.R. (2007): Difficulties in revitalizating public space by CCTV: street prostitution surveillance in the Swiss City of Olten. - In: European Urban and Regional Studies 14, 4: 337-348.

Kutschinske, K. \& V. Meier (2000): «Sich diesen Raum zu nehmen und sich freizulaufen»: Angst-Räume als Ausdruck von Geschlechterkonstruktion. - In: Geographica Helvetica 55, 2: 78-84.

Landolt, S., Schneider, S. \& A. Odermatt (2006): Seeanlagen Zürich: Bedeutung, Nutzungen, Herausforderungen 2005/2006. - Zürich: Geographisches Institut der Universität Zürich.

Löw, M. (2001): Raumsoziologie. - Frankfurt am Main: Suhrkamp.

Massey, D. (2005): For space. - London: Sage Publications.

MitcheLl, D. (2003):The right to the city: social justice and the fight for public space. - New York: Guilford Press.

Mitchell, D. (1995): The end of public space? People's park, definitions of the public, and democracy. - In: Annals of the Association of American Geographers 85, 1: 108-133.

Ostermann, F.O. \& S. TimpF (2009): Use and appropriation of space in urban public parks. GIS methods in social geography. - In: Geographica Helvetica 64,1: 30-36.

PaIN, R.H. (2001): Gender, race, age and fear in the city. - In: Urban Studies 38, 5-6: 899-913.

Paravicini, U. (2003): Public spaces as a contribution to egalitarian cities. - In: Terlinden, U. (ed.): City and gender: international discourse on gender, urbanism and architecture. - Schriftenreihe der Internationalen Frauenuniversität «Technik und Kultur»12, Opladen: Leske+Budrich: 57-80.

Ruhne, R. (2003): Raum Macht Geschlecht: Zur Soziologie eines Wirkungsgefüges am Beispiel von (Un-)Sicherheiten im öffentlichen Raum. - Opladen: Leske+Budrich.

SANDERCOCK, L. (2005): Difference, fear and habitus: a political economy of urban fears. - In: Hillier, J. \& E. RooksBy (eds): Habitus: a sense of place. - Aldershot: Ashgate: 219-234.

Smith, N. (1996): The new urban frontier. Gentrification and the revanchist city. - London, New York: Routledge.

STADT ZÜRICH, GARTENBAU- UND LANDWIRTSCHAFTSAMT (May 2001): Friedrich Traugott Wahlen-Park, Zentrum Zürich Nord: Wettbewerbsprogramm. - http://www. stadt-zuerich.ch/internet/gsz/home/planung/wettbewerbe.html 20.02.2008.

Strauss, A. \& J. Corbin (1998): Basics of qualitative research: techniques and procedures for developing grounded theory. - Thousand Oaks: Sage Publications. Studer, H. (2002): Mädchenräume: landschaftsplanerische Erfahrungen. - In: Kramer, C. (Hrsg.): FREI-Räume und FREI-Zeiten: Raum-Nutzung und Zeit-Verwendung im Geschlechterverhältnis. - Schriften des Heidelberger Instituts für Interdisziplinäre Frauen- und Geschlechterforschung (HIFI) e.V. 5, Baden-Baden: Nomos-Verlagsgesellschaft: 61-76.

VAIOU, D. \& A. Kalandides (2009): Cities of «others»: public space and everyday practices. - In: Geographica Helvetica 64, 1: 11-20.

WARD Thompson, C. (2002): Urban open space in the $21^{\text {st }}$ century. - In: Landscape and Urban Planning 60: 59-72.

WeILACHER,U.(2001):Abstrakte Gärten in der Schweiz: Ernst Cramers Suche nach einem modernen Ausdruck in der Gartenarchitektur. - In: DISP 146: 13-17.

Wesely, J.K. \& E. GaArder (2004): The gendered «Nature» of the urban outdoors: women negotiating fear of violence. - In: Gender \& Society 18, 5: 645-663.

\section{Abstract: Planning, design and use of the public space Wahlenpark (Zurich, Switzerland): functional, visual and semiotic openness}

Wahlenpark is currently one of Zurich's most recent urban public parks. It is located in a neighbourhood which has been totally rebuilt during the last 20 years. Based on a constructivist conception of space, this article looks at the kind of spaces that have been, and still are, produced at Wahlenpark. It is argued that various groups of actors are, and have been, involved in this production of spaces: city planners in the role of constructors, landscape architects in the role of designers and «the population» in the role of users. By defining requirements, city planners constitute space, at first on a mental level «only». As constructors they perform - through the designers' plans - a powerful spacing act: they physically construct a park. Park users in their dual role as actors and «park element» subsequently (re-)produce manifold spaces by uniting social goods and people to spaces (see Löw 2001).

It is argued that openness is an important reference point in the production and appropriation of space at 
Wahlenpark by planners, designers and users, albeit with different meanings. The statements of park users show that they experience openness differently, sometimes even in a contradictory manner, thereby highlighting the variability of subjective perception, resulting in both the inclusion and exclusion of the perceiver. In view of greater inclusiveness of public spaces, a better understanding of the manner in which people perceive and use these spaces is needed.

Keywords: urban free space, subjective perceptions, planning and design, inclusion and exclusion

\section{Zusammenfassung: Planung, Gestaltung und Nutzung des öffentlichen Raums Wahlenpark (Zürich, Schweiz): funktionale, visuelle und semiotische Offenheit \\ Der Wahlenpark ist zurzeit einer von Zürichs neusten öffentlichen Parks. Er liegt in einem Quartier, welches in den letzten 20 Jahren vollständig neu gebaut worden ist. Basierend auf einem konstruktivistischen Raum- verständnis beleuchtet der Artikel die durch verschie- dene Akteursgruppen hergestellten Räume. Für das Beispiel des Wahlenparks werden die folgenden drei Akteursgruppen als zentral erachtet: die Stadtpla- nerinnen und -planer in der Funktion der Bauherr- schaft, Landschaftsarchitektinnen und Künstler in der Funktion der Gestaltenden und «die Bevölkerung» als Endnutzerin. Durch die Spezifizierung von Anfor- derungen, stellen Stadtplanerinnen und -planer einen Raum her, der vorerst «nur» mental ist. Als Bauherr- schaft führen sie sodann - nach den in Pläne gegos- senen Räumen der Gestaltenden - einen machtvollen Akt der Raumproduktion durch. In ihrer dualen Rolle als Handelnde und «Parkelemente» (re-)produzieren Parknutzerinnen und -nutzer anschliessend facetten- reiche Räume, indem sie soziale Güter und Menschen zu Räumen verknüpfen (Löw 2001).}

Der Artikel zeigt, dass Offenheit bei den von Planerinnen, Landschaftsarchitekten und Nutzerinnen hergestellten Räumen ein zentrales Thema ist - wenn auch mit unterschiedlicher Bedeutung. Die Aussagen von Parknutzern und -nutzerinnen verdeutlichen, wie unterschiedlich Offenheit erlebt wird, was wiederum zeigt, wie vielseitig die subjektive Wahrnehmung eines Ortes sein kann. So resultiert denn auch die programmatisch angelegte Offenheit im Wahlenpark gleichzeitig im Ein- und Ausschluss von Parknutzerinnen und -nutzern. Für eine Gestaltung urbaner öffentlicher Räume mit möglichst integrativer Wirkung ist es deshalb dringend notwendig, mehr über die Art und Weise zu wissen, wie Menschen diese Räume wahrnehmen und nutzen.

Schlüsselwörter: städtischer Freiraum, subjektive Wahrnehmungen, Planung und Gestaltung, Einschluss und Ausschluss

\section{Résumé: Aménagement, design et usage de l'espace public du Wahlenpark (Zurich, Suisse): ouverture fonctionnelle, visuelle et sémiotique}

Le Wahlenpark est actuellement l'un des parcs urbains les plus récents de Zurich. Il est situé dans un quartier qui a été entièrement reconstruit durant ces vingt dernières années. Basé sur une conception de l'espace constructiviste, cet article analyse les types d'espaces qui ont été produits au Wahlenpark. L'article suggère que plusieurs groupes d'acteurs sont, et ont été, impliqués dans la production de ces espaces: les aménageurs urbains qui construisent le parc, les architectes paysagistes et les artistes qui le conçoivent et la «population» qui l'utilise. En définissant des normes, les aménageurs urbains sont tout d'abord producteurs d'un espace mental. En tant que constructeurs, ils construisent en outre physiquement le parc en suivant les plans des designers. Les utilisateurs du parc, dans leur rôle dual d'acteurs et d'éléments du parc, (re)produisent ensuite de multiples espaces en unifiant les biens sociaux et les gens aux espaces (voir Löw 2001).

L'article montre que l'ouverture est un thème central dans la production et l'appropriation des espaces du Wahlenpark par les aménageurs, les architectes paysagers et les usagers, avec des significations qui peuvent cependant varier. Les déclarations des usagers montrent qu'ils expérimentent l'ouverture différemment, parfois même d'une manière contradictoire, illustrant la variabilité des perceptions subjectives. Il en résulte à la fois l'inclusion et l'exclusion des usagers. Dans la perspective d'une plus grande insertion des espaces publics, une meilleure compréhension de la manière dont les gens perçoivent et utilisent ces espaces est nécessaire.

Mots-clés: espace libre urbain, perceptions subjectives, planification et conception, inclusion et exclusion

Dipl.-Geogr. Heidi Kaspar, Dr. Elisabeth Bühler, Division of Economic Geography, Department of Geography, University of Zurich, Winterthurerstrasse 190, $\mathrm{CH}-8057$ Zurich, Switzerland.

e-mail:

heidi.kaspar@geo.uzh.ch

elisabeth.buehler@geo.uzh.ch

Manuskripteingang/received/manuscrit entré le 8.6.2008

Annahme zum Druck/accepted for publication/accepté pour l'impression: 27.3.2009 